UDK: 811.163.4(497.6)

DOI: $10.33669 / \mathrm{KJ} 2021-32-09$

primljeno / received: 2.9 .2021 .

prihvaćeno / accepted: 16. 12.2021.
Pregledni naučni rad

\section{Edina Kečo}

Univerzitet u Sarajevu - Institut za jezik

Hasana Kikića 12, Sarajevo

Bosna i Hercegovina

edina.vrazalica@izj.unsa.ba

\title{
Frazemska sinonimija u Pobunama Derviša Sušića
}

Sažetak: Prisustvo frazemske sinonimije analizira se na korpusu književnog djela Pobune Derviša Sušića. Cilj je objasniti upotrebu frazemske istoznačnosti i bliskoznačnosti u navedenom djelu, kao i upotrebu frazemskih varijanti. Korištene su metode analize i deskripcije. Dobijeni rezultati upućuju na to da istoznačnost frazema nije pronađena u djelu, ali da je frekventna upotreba frazema bliskih značenja, kao i varijantnih oblika frazema. $\mathrm{Na}$ osnovu pronađenih, analiziranih i opisanih frazema utvrđeno je da frazeme iz analiziranog korpusa i frazeme iz konsultiranih izvora nemaju ista značenja, već bliska, iznijansirana, dok značenje varijantnih oblika frazema ostaje nepromijenjeno. U analiziranom korpusu pronađeni frazemi su većinom općepoznati, iako određeni primjeri frazema nisu zabilježeni u konsultiranim izvorima.

Ključne riječi: frazemska sinonimija, bliskoznačnost, frazemske varijante, Pobune

\section{Uvod}

Iako frazeme u načelu imaju čvrstu strukturu, mogu se primijetiti promjene u njihovoj strukturi te njihovom leksičkom sastavu, pa se sastavnice nekih frazema mogu zamijeniti drugima, a da njihova značenja ostanu sinonimna. Petrović (2005: 122) navodi da se sinonimija najčešće shvata kao potpuna jednakost te kao velika bliskost / sličnost. Dalje (2005: 129) tvrdi da su sinonimna dva izraza kada u konkretnom kontekstu obuhvataju isti ili bliski potencijalni sadržaj. Smatra da je 
sinonimija odnos među jedinicama u leksiku, a da sinonimičnost ovisi o određenom kontekstu i da egzistira samo na tekstualnoj razini.

Unutar sinonimije poznati su termini istoznačnost i bliskoznačnost. U lingivistici se dovodi u pitanje da li postoje istoznačni sinonimi. Petrović (2005: 123) navodi kako svaki sinonim nosi svoja obilježja (dijalekatsko, profesionalno, lingvističko) i u svakom se mogu prepoznati različite namjere govornika, dok Tafra (1996: 82) tvrdi da se istoznačnicama smatraju lekseme koje imaju značenje koje je prihvaćeno za sve govornike određene jezične zajednice (denotativno značenje). Smatra da istoznačni sinonimi trebaju ispunjavati kriterij identičnosti (kompjuter i računar).

Također, Riđanović (1998: 244) smatra da glavni razlog nepostojanja apsolutnih sinonima treba tražiti u činjenici da skoro svaka riječ ima više značenja pa, iako se određena značenja dviju riječi podudaraju, neka ipak nisu podudarna.

Kada je riječ o frazemskim sinonimima, oni predstavljaju "frazeološke jedinice koje su bliske ili gotovo iste po značenju i smislu i označavaju isti pojam, ali se međusobno mogu razlikovati po nijansi značenja, ili po stilskoj boji, a u nekim primjerima po oba ova elementa..." (Tanović 2000: 43). Kao što je rijetka apsolutna (potpuna) sinonimija leksema, tako je rijetka i apsolutna sinonimija frazema jer je kontekst neophodan u određivanju njihovog značenja. Uvid u značenjski aspekt frazema je ključan. Hrustić (2001: 101) navodi da se sinonimija primarno temelji na značenjskim odlikama frazema i najčešće se predstavlja preko značenjskih polja. Šiljak-Jesenković (2003: 138) navodi da nema potpune sinonimije, već se može govoriti o bliskim značenjima frazeosinonima. Iz svega navedenog, može se reći da frazemska sinonimija predstavlja podudaranje bitnih semantičkih obilježja dvaju ili više frazema različitog leksičkog sastava.

\section{Analiza korpusa}

Korpus istraživanja, kako je ranije istaknuto, predstavlja zbirka pripovjedaka Pobune. Glavni izvor za provjeru izdvojene građe su frazeološki 
rječnici bosanskoga jezika (Tanović 2000; Lukić 2005; Mahmutović 2012; Kasumović - Nikolić 2018), potom frazeološki rječnici i bibliografije hrvatskoga jezika (Matešić 1982; Fink-Arsovski - Kovačević - Hrnjak 2017) te općejezični rječnik bosanskoga jezika (Halilović Palić - Šehović 2010). Kada se za to ukazala potreba, konsultirana je Baza frazema hrvatskoga jezika. Radi preglednosti i jasnoće uz navedene primjere frazema navodi se skraćenica prezimena autora, skraćenica pripovijetke iz koje je preuzet primjer te godina i stranica na kojoj se taj primjer nalazi u navedenoj zbirci.

Jezički kontekst je neophodan u određivanju značenja frazema, pa će se u ovom radu značenja frazema svesti na ono koje je uvjetovano određenim kontekstom.

U radu se frazeološka istoznačnost posmatra na način da su sinonimni frazemi zamjenjivi u svim kontekstima. Budući da je kontekst neizostavan u određivanju značenja frazema, istoznačnost frazema se dovodi u pitanje. Tanović (2000: 45) navodi da zamjena jedne frazeme drugom zavisi od sljedećih elementa frazeološke jedinice: "stepena semantičke bliskosti ili sličnosti globalnog značenja i smisla frazeoloških jedinica, strukture frazeoloških jedinica, mogućnosti sintaksičke spojivosti sa drugim dijelovima konteksta, stilske boje frazeoloških sinonima i njihovog emocionalnog naboja”.

Frazemska istoznačnost nije pronađena u analiziranom korpusu, ali se može govoriti o frazemskim bliskoznačnicama, pa će posebna pažnja biti posvećena frazemama koje imaju bliska značenja. Bliskoznačnost frazema podrazumijeva, u ovom radu, djelimičnu mogućnost zamjenjivanja frazema u određenom kontekstu.

Većina pronađenih frazema $\mathrm{u}$ analiziranom korpusu predstavlja značenjske sinonime u odnosu na rječničke izvore. Kao što je već rečeno, značenja pronađenih primjera frazema su vezana za kontekst, pa tako nije nužno da ih potvrđeni primjeri frazema iz rječničkih izvora mogu zamijeniti. U radu će se pored primjera navoditi i rječnički oblici frazema.

U korpusu su pronađene sljedeće frazeme: 
- $\quad$ motati konce (“(...) da li motam duge konce ulizice i čovjeka tanka poštenja (...).”, SP 1991: 44): mrsiti / pomrsiti (smrsiti) komu konce (Matešić 1982: 354), pomrsiti / zamrsiti konce komu (FinkArsovski - Kovačević - Hrnjak 2017: 390). Frazema koju navodi autor te frazeme potvrđene u rječnicima imaju značenje "pokvariti kome planove, namjere i sl.", ali za razliku od leksema pomrsiti i zamrsiti, leksema motati daje efekat neprekidnog trajanja radnje splekarenja, obmanjivanja te zavaravanja.

povjeriti dušu (“(...) nego pruži mi ruku, a povjeri dušu (...)., SK 1991: 113): otvoriti dušu / srce (Halilović - Palić - Šehović 2010: 860); otkriti dušu i srce (Matešić 1982: 114). Iako frazeme povjeriti dušu te otvoriti / otkriti dušu imaju sinonimna značenja, upotrebom lekseme povjeriti književnik želi naglasiti povjerenje između dvije osobe, pa se može govoriti o nijansama u značenju. Leksema povjeriti znači da se traži od određene osobe da se dalje ne širi ono što je rečeno i da to ostaje između dvije osobe (Halilović Palić - Šehović 2010: 987-988).

- natrljati ranu solju, koja ima značenje "otežavati kome već teško stanje” (“(...) meso da otkine i drhtavu ranu solju natrlja!”, SP 1991: 59). Frazema u obliku natrljati ranu solju nije naveden ni u jednom konsultiranom rječniku niti internetskoj bazi. Matešić (1982: 626) navodi: metnuti (staviti) soli na živu ranu. U Bazi frazema hrvatskog jezika navodi se: staviti /komu/ sol na živu ranu. Iako navedena frazema te frazeme iz konsultiranih izvora imaju sinonimna značenja "podsjetiti koga na što bolno / neugodno, povrijediti čije osjećaje neumjesnim spominjanjem neprijatnih događaja”, autor svojom konstrukcijom frazeme leksemom natrljati pojačava značenje frazeme. Na taj način se ukazuje na intenzivniju, veću i jaču bol koja je prouzrokovana, pa možemo govoriti o nijansama u značenju.

- $\quad$ pripeći pod tabanima (“(...) ali kad je i kapetanu pripeklo pod tabanima (...).”, SSJ 1991: 206): gori komu pod tabanima (Matešić 1982: 687); gori (komu) pod tabanima (Baza). Pronađena frazema u korpusu i frazeme potvrđene u izvorima imaju značenje 
“nalaziti se u teškoj situaciji / opasnosti”, ali se može govoriti o nijansama u značenjima jer pripeći znači “jako ugrijati”, a gorjeti znači "biti u plamenu".

Primjećujemo da pronađeni primjeri frazema u poređenju sa potvrđenim frazemama iz rječničkih izvora imaju bliska značenja, ali ne i istoznačna, već postoje nijanse u značenjima. Promjena sastavnica unutar frazema utječe na različita značenjska obilježja, što upućuje i na nejednaku distribuciju i upotrebu određenih frazema.

$\mathrm{U}$ analiziranom korpusu pronalaze se dva primjera frazema sa leksemom oko / oči:

- $\quad$ sasuti u oči ("I ja mu u oči očima sasuh naredbu (...)., SK 1991: 95): reći komu što u oči (Matešić 1982: 563), govoriti (kazati / reći) u oči (komu što) (Fink-Arsovski - Kovačević - Hrnjak 2017: 571). Kao što se može primijetiti u izvorima se pronalazi ovaj frazem sa leksemama reći / govoriti / kazati, dok Sušić u zbirci pripovjedaka upotrebljava leksemu sasuti u frazemi sasuti u oči koja ima značenje "mnogo toga reći brzo i naglo u kratkom vremenskom periodu”. Leksema sasuti ima ekspresivno značenje u odnosu na lekseme reći / govoriti / kazati, pa se može govoriti o nijansama u značenju.

- premjeriti / izmjeriti okom ("Premjerim je, izmjerim okom, sve na njoj sliveno i srezano po savršnoj mjeri i razmjeri., SK 1991: 116): odmjeriti koga pogledom (Matešić 1982: 408). Specifično je da književnik pored lekseme izmjeriti koristi leksemu premjeriti koja ima značenje "mjeriti objekat ili prostor" (Halilović - Palić Šehović 2010: 1013), dok je leksemama izmjeriti i odmjeriti, koja je pronađena u konsultiranom rječniku, jedno od značenja "obuhvatiti pogledom” (Halilović - Palić - Šehović 2010: 438, 801), što je i značenje navedene lekseme.

U rječničkim izvorima zabilježeno je mnogo frazema koje u svom sastavu imaju leksemu $k r v$, a u analiziranom korpusu pronađene su dvije frazeme sa tom sastavnicom: prokopati krv na oči te platiti što kapljom krvi: 
- prokopati krv na oči ("Nemoj dalje, krv mi odmah prokopa na oči!”, SSJ 1991: 195): naliti se krv u oči (Kasumović - Nikolić 2018: 246); jurnula / navalila mi (mu...) krv u glavu, krv mu se navukla / pala na oči (Halilović - Palić - Šehović 2010: 562); ide (jurne, udari $i$ dr.) komu krv u glavu (u lice, u obraze) (Matešić 1982: 289). Iz navedenih izvora možemo primijetiti da autori ne navode frazemu koja je pronađena $\mathrm{u}$ analiziranom korpusu, ali da je značenje nabrojanih frazema iz izvora blisko frazemi prokopati krv na oči - "razljutiti se, postati uzrujan i sl.. Radi postizanja jačeg efekta, frazema prokopati krv na oči, koja je uvjetovana kontekstom, ima značenje "razbjesniti se".

- $\quad$ platiti što kapljom krvi (“(...) svaku njegovu suzu bi kapljom svoje krvi platila (...)., SKV 1991: 221-222): platiti glavom / životom / kožom / krvlju (Halilović - Palić - Šehović 2010: 907); plaćati / platiti što krvlju (Matešić 1982: 291); platiti što krvlju (Baza). Autor leksemom kaplja intenzivira i pojačava značenje. Iako značenje frazeme ("smrtno stradati") možemo smatrati sinonimnim $\mathrm{u}$ odnosu na potvrđene frazeme u konsultiranim izvorima, moramo napomenuti da su prisutne nijanse u značenju pa tako se leksemom kaplja naglašava u kojoj mjeri i na koji način je pokazana spremnost na žrtvovanje.

U prethodnim pasusima pronađeni primjeri frazema su se poredili sa onima iz rječničkih izvora, ali se u analiziranom korpusu pronalaze i frazeme koje se mogu posmatrati jedna naspram druge. Kao što smo vidjeli, određena se sastavnica frazema može zamijeniti i semantički bliskom riječju. Tako $\mathrm{u}$ analiziranom korpusu pronalazimo primjere frazema biti neko na vrhu i biti neko na čelu:

“(...) dok je nastala ova uprava kojoj si ti na vrhu i na čelu?” (SP 1991: 83) U izvorima koji su korišteni za provjeru frazema pronalaze se sljedeći frazemi: doći / izbiti na čelo (Halilović - Palić - Šehović 2010: 132); doći / stati / staviti na čelo čega (Matešić 1982: 63); postaviti (koga) na čelo, stajati na čelu (čega), biti na čelu (čega) (Baza). U izvorima se ne pronalaze frazeme biti / stajati / doći na vrh (čega). Pronađeni primjeri u 
korpusu imaju značenje: "biti na vrhu kakva poretka”. Ono što je posebno zanimljivo jest da autor $\mathrm{u}$ istoj rečenici koristi frazeme biti na vrhu $\mathrm{i}$ biti na čelu kojima želi pojačati efekat govora lika.

Drugi pronađeni primjer promjene semantički bliskih riječi $\mathrm{u}$ analiziranom korpusu su frazeme stati nekome na rep i stati nekome na žulj:

"Stani mu na rep, vidjećeš odmah." (SSJ 1991: 156)

"Stane li ti ko na žulj (...)." (SSJ 1991: 182)

U konsultiranim rječnicima i Bazi pronalazimo sljedeće frazeme: stati kome na žulj (Halilović / Palić / Šehović 2010: 1247); stati / ne stati kome na žulj (Kasumović - Nikolić 2018: 404); stati komu na žulj (Matešić 1982: 807) te stati na rep (Kasumović - Nikolić 2018: 405); stati (nagaziti) komu na rep (Matešić 1982: 567). Autori za ova dva primjera frazema navode različita značenja: stati kome na žulj: "izazvati čiji bijes protiv sebe" (Halilović - Palić - Šehović 2010: 1247); "namjerno (ne)naljutiti koga, (ne)izazvati čiji bijes” (ljutnju) (Kasumović - Nikolić 2018: 404); "dirnuti koga u osjetljivo mjesto, uvrijediti koga” (Matešić 1982: 807) te stati kome na rep: "zaustaviti, onemogućiti, spriječiti koga u čemu" (Kasumović - Nikolić 2018: 405); “doskočiti komu, spriječiti koga; izazvati koga, učiniti komu što neugodno" (Matešić 1982: 567). Kao što je već rečeno, za određivanje značenja frazema bitan je kontekst, pa tako pronađeni primjeri iz analiziranog korpusa imaju značenje "naljutiti / izazvati koga".

U drugom dijelu rada bavit ćemo se frazemskim varijantama. Derviš Sušić u Pobunama upotrebljava i frazemske varijante koje predstavljaju inačice frazema pronađenih u rječničkim izvorima. Kada je riječ o frazemskim varijantama, bitno je naglasiti da one moraju zadržavati isto značenje. Kolenić (1998: 377-381) smatra da se riječi sličnog značenja ponekad mogu zamijeniti, ali samo ako i dalje prepoznajemo frazem. Šiljak-Jesenković (2003: 52-53) navodi da mnogi autori ne preporučuju vršenje bilo kakvih zamjena frazeloških komponenti niti njihovog rasporeda kada je u pitanju struktura frazema jer takav pristup narušava pitanje sintaksičke i semantičke stabilnosti frazema. U nekim slučajevima može doći do gubljenja značenja frazema nakon zamjene lekseme 
njenim sinonimom. Naglašava da varijantne oblike ne treba smatrati narušavanjem navedene stabilnosti.

Činjenica je da neki frazemi imaju svoje varijantne oblike. Kada su u pitanju leksičke varijante, one nastaju zamjenom jedne sastavnice frazeme sinonimnom leksemom. U korpusu se pronalazi nekoliko primjera frazemskih varijanata:

- pokazati drugo lice (“(...) i dovoljno da može pobjeći kad mu ti i ono drugo lice svoje pokažeš., SK 1991: 112-113): pokazati pravo lice (Matešić: 1982: 312), pokazati (svoje) pravo lice (FinkArsovski - Kovačević - Hrnjak 2017: 450), pokazati svoje pravo lice (Kasumović / Nikolić 2018: 336). Iako se u konsultiranim rječnicima pronalaze primjeri navedene frazeme sa leksemom pravo (koja je prema vrsti riječi pridjev) i leksema drugo (koja je prema vrsti riječi redni broj), u kontekstu imaju isto značenje. Navedena frazema je sinonimna sa frazemama pronađenim $u$ rječničkim izvorima i imaju značenje: "otvoreno iznijeti / priznati / otkriti namjere", iako navedena frazema iz korpusa u kontekstu znači "otkriti loše namjere".

- $\quad$ prizemna pamet ("Prizemna pamet seljačka ne zna daleka čvorišta sudbine (...).", SSJ 1991: 200): biti kratke / plitke pameti (Halilović - Palić - Šehović 2010: 871); biti plitke pameti, biti kokošje pameti, biti kratke (rijetke) pameti (Matešić 1982: 442); biti plitke pameti (Baza). ${ }^{1}$ Leksema prizemno podrazumijeva neizdizanje visoko iznad površine zemlje, a leksema plitko podrazumijeva malu dubinu. Autor frazemom prizemna pamet želi modificirati već ustaljenu frazemu plitka pamet. Ove frazeme imaju sinonimno značenje i u transponiranom značenju upućuju na intelektualnu površnost.

- $\quad$ tovariti teret za vrat (“(...) kako se i inače radi kad se drugom tovari svoj teret za vrat.", SSJ 1991: 151). U rječnicima pronalazimo sljedeće potvrde: imati koga, što na vratu (za vratom) (Matešić 1982: 757), imati na vratu koga (Fink-Arsovski - Kovačević - Hrnjak

1 Internetska Baza frazema hrvatskoga jezika. 
2017: 913). Izborom lekseme tovariti frazema tovariti teret za vrat dobija značenje "nametati šta kome kao obaveznu brigu, obavezu" te "opteretiti koga". Autor upotrebom navedene lekseme želi postići jači efekat. Frazema tovariti teret $z a$ vrat se može smatrati sinonimnom sa leksemama navedenim iz rječničkih izvora, iako pronađeni primjer iz korpusa ima pojačano značenje u odnosu na ona navedena u rječnicima ("imati koga na teretu", "brinuti o kome").

Sljedeći primjeri frazemskih varijanata se posebno ističu:

biti prebrz na jeziku ("Politikom se ne smiješ baviti jer si prebrz na jeziku (...)., SPMV 1991: 223): biti brz na jeziku (Matešić 1982: 216; Halilović - Palić - Šehović 2010: 471; Fink-Arsovski - Kovačević - Hrnjak 2017: 348). U primjeru koji autor navodi uočavamo prefiks pre-. Lekseme prebrz i brz predstavljaju tvorbene varijante. Pošto je frazema biti brz na jeziku frekventnija u upotrebi, možemo reći da je frazema biti prebrz na jeziku njena tvorbena frazeološka varijanta.

- gladno oko (“(...) znam ja šta je glad i gladno dječije oko!”, SSJ 1991: 189) - ova frazema predstavlja varijantu frazeme gladne oči, koja je mnogo češća u govoru. Pronađeni primjer predstavlja morfološku varijantu frazeme gladne oči. Umjesto očekivanog množinskog oblika, autor koristi jedninu. Ova frazema nije pronađena u konsultiranim rječnicima niti Bazi.

uvrtiti sebi u glavu (“(...) a onda je iznenada sebi uvrtio u glavu da je on prava radnička klasa (...)., SPMV 1991: 236): uvrtjeti (sebi) u glavu (Halilović - Palić - Šehović 2010: 1410). Leksema uvrtiti mogla bi se smatrati varijantom lekseme uvrtjeti, pa tako i pronađena frazema u korpusu predstavlja varijantni oblik frazeme $u v r$ tjeti sebi u glavu. Odabirom ove lekseme u pronađenoj frazemi autor ističe kolokvijalni (narodni) govor likova analizirane zbirke pripovjedaka. Autori konsultiranog rječnika navode značenje ovog frazema: "biti potpuno zaokupljen nekom neostvarivom ili 
teško ostvarivom zamisli, idejom” što predstavlja i značenje pronađenog frazema $\mathrm{u}$ analiziranom korpusu.

Za razliku od bliskoznačnih frazema kod kojih postoje nijanse u značenju i koji međusobno u svakom kontekstu ne moraju biti zamjenjivi, frazemske varijante su zamjenjive, a promjene koje su izvršene u varijantnim oblicima nisu utjecale na promjenu značenja.

\section{Zaključak}

Posljednjih godina pojavio se interes za izučavanjem frazema u lingvističkoj bosnistici. Pronađeni primjeri frazema iz analiziranoga korpusa pokazuju da nisu pronađene istoznačne frazeme te da je vrlo česta upotreba bliskoznačnih frazema. Također, pronađeni su primjeri varijantnih oblika frazema.

Kada je u pitanju bliskoznačnost, pronađeni primjeri frazema imaju bliska značenja sa onim frazemama potvrđenim u konsultiranim izvorima te su ta značenja iznijansirana. Iako analizirane frazeme imaju bliska značenja sa frazemama iz konsultiranih izvora, to ne znači da će u određenom kontekstu biti zamjenjive. Upotrebom određenih sastavnica unutar frazema autor Pobuna ekspresivno oslikava likove, ali i radnju u pripovijetkama.

S druge strane, kada su u pitanju varijantni oblici frazema, njihovo značenje ostaje isto kao i kod frazema potvrđenih u rječnicima, iako autor upotrebom varijantnog oblika frazema želi pojačati efekat svojih rečenica.

U analiziranom korpusu pronađeni frazemi su većinom općepoznati, iako određeni primjeri pronađenih frazema nisu zabilježeni u konsultiranim izvorima.

\section{Popis skraćenica}

SK - Sušić, Kaimija

SKV - Sušić, Kad se vratim

SP - Sušić, Plaćenik 
SPMV - Sušić, Preko mutne vode

SSJ - Sušić, Seljačka jadikovka

\section{Izvori}

Fink-Arsovski, Željka; Kovačević, Barbara; Hrnjak, Anita (2017): Bibliografija hrvatske frazeologije - frazeobibliografski rječnik, Knjigra, Zagreb.

Halilović, Senahid; Palić, Ismail; Šehović, Amela (2010): Rječnik bosanskoga jezika, Filozofski fakultet u Sarajevu, Sarajevo.

Kasumović, Ahmet; Nikolić, Marijana (2018): Rječnik frazema bosanskoga je$z i k a$, Institut za humanu rehabilitaciju, Tuzla.

Lukić, Zlatko (2005): Bosanska sehara: poslovice, izreke $i$ fraze u BiH, Šahinpašić, Sarajevo.

Mahmutović, Alisa (2012): Kao frazeološki rječnik - Rječnik frazema s poredbenom česticom "kao”, Dobra knjiga - Synopsis, Sarajevo - Zagreb.

Matešić, Josip (1982): Frazeološki rječnik hrvatskoga ili srpskog jezika, Školska knjiga, Zagreb.

Sušić, Derviš (1991): Pobune, Svjetlost, Sarajevo, 31-276.

\section{Internetski izvori}

http://frazemi.ihjj.hr/

\section{Literatura}

Hrustić, Meliha (2001): Kontrastivna analiza frazeoloških izraza sa komponentom Kopf/glava u njemačkom i u b/h/s jeziku, Tuzla.

Kolenić, Ljiljana (1998): Riječ o riječima. Iz hrvatske leksikologije i frazeologije 17. i 18. stoljeća, Sveučilište Josipa Juraja Strossmayera u Osijeku, Pedagoški fakultet, Osijek.

Petrović, Bernardina (2005): Sinonimija i sinonimičnost u hrvatskome jeziku, Hrvatska sveučilišna naklada, Zagreb.

Riđanović, Midhat (1998): Jezik i njegova struktura, Savremeno lingvističko osvjetljenje, Šahinpašić, Sarajevo. 
Šiljak-Jesenković, Amina (2003): Nad turskim i bosanskim frazikonom: semantički, sintaktički, lingvostilistički i sociolingvistički aspekt, Orijentalni institut, Sarajevo.

Tafra, Branka (1996): "Bliskoznačni odnosi u leksiku”, Filologija: časopis Razreda za filološke znanosti Hrvatske akademije znanosti i umjetnosti 26, 73-84.

Tanović, Ilijas (2000): Frazeologija bosanskog jezika, Dom štampe, Zenica.

Vrljić, Stojan (1990) "Frazeološke jedinice kao sredstvo konciznog izraza", Književni jezik 19/4, Institut za jezik, Sarajevo, 195-204. 


\section{Phraseological synonymy in Pobune by Derviš Sušić}

Abstract: The presence of phraseological synonymy is analyzed in the corpus of the literary work Pobune by Derviš Sušić. The aim is to explain the use of phraseological synonymy and close meanings of phrasems in the mentioned work, as well as the use of phrasems variants. Methods of analysis and description were used. The obtained results indicate that the synonymous phrasems wasn't found in the work, but that the frequent use close meanings of phrasems, as well as variant forms of phrasems. Based on the found, analyzed and described phrasems, it was determined that phrasems from the analyzed corpus and phrasems from consulted sources don't have the same meaning, but close, nuanced, while the meaning of variant forms of phrasems remains unchanged. The phrasems found in the analyzed corpus are mostly generally known, although certain examples of phrasems haven't been recorded in the consulted sources.

Key words: phraseology, phraseological synonymy, close meanings of phrasems, variants of phrasems, Pobune

Izjava autora o nepostojanju sukoba interesa i poštivanju općih etičkih kodeksa:

Autor potvrđuje da ne postoji nikakav stvarni ili mogući sukob interesa vezan za ovaj tekst te da je tekst napisan u skladu s etičkim kodeksima prema preporukama COPE (Committee of Publishing Ethics). 